\title{
Rancang Bangun Antena Mikrostrip Bowtie Pada Frekuensi 5,2 Ghz
}

\author{
Aprinal Adila Asril ${ }^{1^{*}}$, Lifwarda $^{2}$, Yul antonisfia ${ }^{3}$ \\ ${ }^{123}$ Jurusan Teknik Elektro, Politeknik Negeri Padang \\ aprinal@pnp.ac.id \\ Kampus Politeknik Negeri Padang, Limau Manis Padang
}

\begin{abstract}
Microstrip antennas are very concerned shapes and sizes. Can be viewed in terms of simple materials, shapes, sizes and dimensions smaller antennae, the price of production is cheaper and able to provide a reasonably good performance, in addition to having many advantages, the microstrip antenna also has its drawbacks one of which is a narrow bandwidth. In this research will be designed a microstrip antenna bowtie which works at a frequency of $5.2 \mathrm{GHz}$ which has a size of $68 \mathrm{~mm} \times 33 \mathrm{~mm}$ groundplane. For the length and width of $33 \mathrm{~mm} \times 13 \mathrm{~mm}$ patch. This antenna is designed on a printed cicuit board (PCB) FR4 epoxy with a dielectric constant of 4.7 and has a thickness of 1,6mm. This bowtie microstrip antenna design using IE3D software. This antenna has been simulated using IE3D software showed its resonance frequency is $5.270 \mathrm{GHz}$ with a return loss $-23595 \mathrm{~dB}$ bandwidth of $230 \mathrm{MHz}$, VSWR 1,142, unidirectional

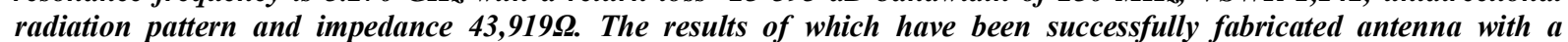
resonant frequency of $5.21 \mathrm{GHz}$ with a return loss $-16.813 \mathrm{~dB}$ bandwidth of $79 \mathrm{MHz}$, VSWR 1.368, unidirectional

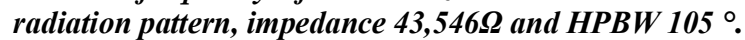

Keywords:Bowtie microstrip, VSWR, HPBW, radiation pattern

Abstrak-Antena Mikrostrip sangat memperhatikan bentuk dan ukuran. Dapat dilihat dari segi bahan yang sederhana, bentuk, ukuran dan dimensi antenanya lebih kecil, harga produksi lebih murah dan mampu memberikan kinerja yang cukup baik, selain memiliki banyak kelebihan, antena mikrostrip juga memiliki kekurangan salah satunya adalah bandwidth yang sempit. Pada penelitian ini akan dirancang sebuah antenna mikrostrip bowtie yang bekerja pada frekuensi 5,2 GHz yang memiliki ukuran groundplane $68 \mathrm{~mm}$ x $33 \mathrm{~mm}$. Untuk ukuran panjang dan lebar patch 33mm x 13mm. Antena ini di desain pada Printed Cicuit Board (PCB) FR4 Epoksi dengan konstanta dielektrik 4,7 dan memiliki ketebalan 1,6mm. Antena mikrostrip bowtie ini di desain menggunakan software IE3D. Antena ini telah dilakukan simulasi dengan menggunakan software IE3D didapatkan hasil frekuensi resonansinya adalah 5,270 GHz dengan return loss $-23.595 \mathrm{~dB}$, bandwidth $230 \mathrm{MHz}$, VSWR 1,142, pola radiasi unidirectional dan

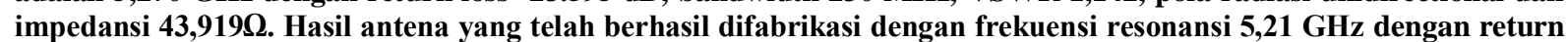

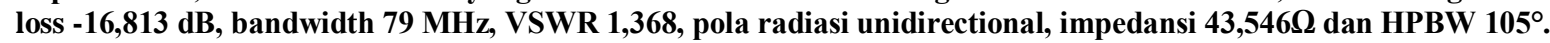

Kata kunci:Antena mikrostrip bowtie,VSWR, HPBW, pola radiasi

(C) 2018Elektron Jurnal Ilmiah

\section{PENDAHULUAN}

Antena adalah suatu piranti transisi antara saluran transmisi dengan ruang hampa dan sebaliknya (Adhe,2010), sehingga antena berfungsi sebagai pemancar atau penerima gelombang elektromagnetik. Antena bisa dianggap sebagai tulang punggung sistem nirkabel. Salah satu antena yang cocok dipakai untuk aplikasi perangkat kecil adalah antena mikrostrip yang mempunyai sifat low profile. Teknologi mikrostrip menggunakan sebuah medium (substrate) yang memiliki karakteristik dielektrik yang dapat digunakan untuk menghantarkan atau suatu propagasi gelombang elektromagnetik melalui teknologi MIC (Microstrip Integrated Circuit ) untuk frekuensi gelombang mikro. Meskipun termasuk dalam antena dengan gain rendah, keberadaannya sangat cocok untuk digunakan pada perangkat-perangkat yang berdimensi kecil. [1].

Antena mikrostrip bowtie merupakan pengembangan desain antena dari bentuk patch segitiga (triangel). Antena bowtie pada dasarnya termasuk dalam jenis antena dipole bentuk kawat dengan penambahan beberapa elemen untuk dapat melakukan pengaturan impedansi input antena. Pada perkembangan selanjutnya pada antena bowtie bentuk kawat dikonversikan ke dalam bentuk patch. Antena bowtie bentuk patch memiliki ukuran yang lebih kecil dari antena bowtie bentuk kawat. Kelebihan bentuk bowtie adalah dapat digunakan untuk meradiasikan atau menangkap radiasi berbagai frekuensi" [2]. Hasil perancagan antena Mikrostrip Bowtie pada Frekuensi 5,2 GHz dapat digunakan untuk sistem telekomunikasi yang berkerja dalam frekuensi $5,2 \mathrm{GHz}$.

\section{METODOLOGI}

\section{A. Teknik Pencatuan Line Feed Dan Impedansi}

Perancangan antena mikrostrip bowtie ini menggunakan teknik pencatuan line feed dan impedansi masukan (impedansi karakteristik) $50 \Omega$. 
Jenis substrate yang digunakan untuk antena mikrostrip ini akan mempengaruhi parameterparameter dalam perancangan, karena setiap substrate memiliki parameter-parameter yang berbeda. Parameter yang perlu diperhatikan adalah konstanta dielektrik relatif substrate $\left(\varepsilon_{\mathrm{r}}\right)$ dan tebal substrate $(\mathrm{h})$. Pada perancangan ini menggunakan jenis substrate FR4 Epoxy dengan konstanta dielektrik 4,7 dan ketebalan substrate 1,6. Berikut merupakan proses perhitungan panjang gelombang antena untuk desain antena bowtie diambil dari persamaan (1):

$$
\begin{aligned}
\lambda=\frac{c}{f} & =\frac{3 \times 10^{9}}{5,2 \times 10^{9}} \\
& =0,05769 \mathrm{~m} \\
& =5,77 \mathrm{~cm} \\
& =57,7 \mathrm{~mm}
\end{aligned}
$$

Berikut merupakan proses perhitungan ukuran patch untuk antena mikrostrip bowtie diambil dari persamaan (2) dan (3):

$$
\begin{aligned}
\mathrm{a} & =\frac{1.6 \lambda}{\sqrt{\varepsilon_{\mathrm{x}}}} \\
& =\frac{1.6 \times 57.7 \mathrm{~mm}}{\sqrt{4,7}} \\
& =43 \mathrm{~mm} \\
\mathrm{~b} & =\frac{0.5 \lambda}{\sqrt{\varepsilon_{\mathrm{x}}}} \\
& =\frac{0.5 \times 57,7 \mathrm{~mm}}{\sqrt{4,7}} \\
& =13 \mathrm{~mm}
\end{aligned}
$$

Berdasarkan proses hitungan diatas dengan menggunakan persamaan (1), (2) dan (3) maka didapatkan ukuran patch dengan panjang "a" adalah $43 \mathrm{~mm}$ dan panjang "b" yaitu $13 \mathrm{~mm}$. Antena ini di desain memiliki 92 x $33 \mathrm{~mm}$ di sesuaikan dengan ukuran patch. Berikut merupakan gambar desain dari antenna mikrostrip bowtie.

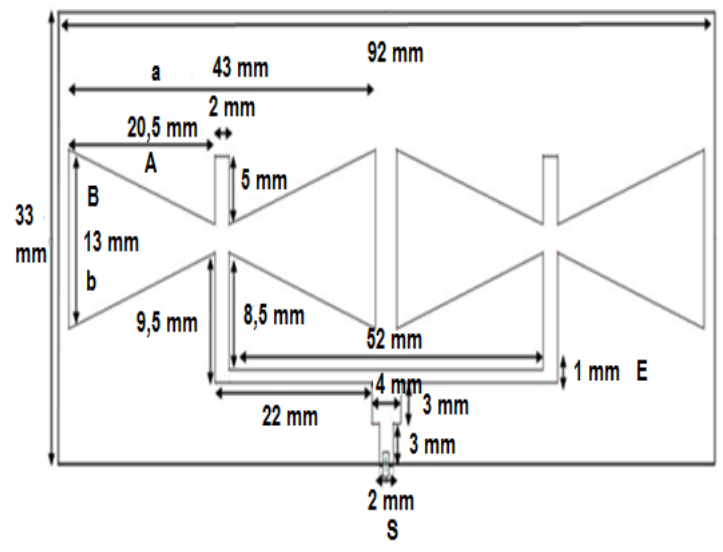

Gambar 2. Rancangan Awal Antena Mikrostrip Bowtie

\section{B. Perancangan Menggunakan Software IE3D}

Sebelum membuat antena terlebih dahulu dirancang bentuk antena yang diinginkan. Pada perancangan antena mikrostrip bowtie ini penulis merancang dengan menggunakan software simulasi antena mikrostrip IE3D. Adapun hal-hal yang perlu diperhatikan dalam merancang antena dengan software IE3D adalah:

1. Spesifikasi bahan PCB (Printed Circuit Board) double layer yang meliputi ketebalan $1.6 \mathrm{~mm}$, dan konstanta dielektrik 4.7.

2. Ukuran antena yang meliputi besarnya bidang patch dan groundplane.

3. Frekuensi kerja yang digunakan, disini penulis menggunakan frekuensi 5,2 GHz.

Berikut desain patch antena mikrostrip bowtie mengunakan software IE3D

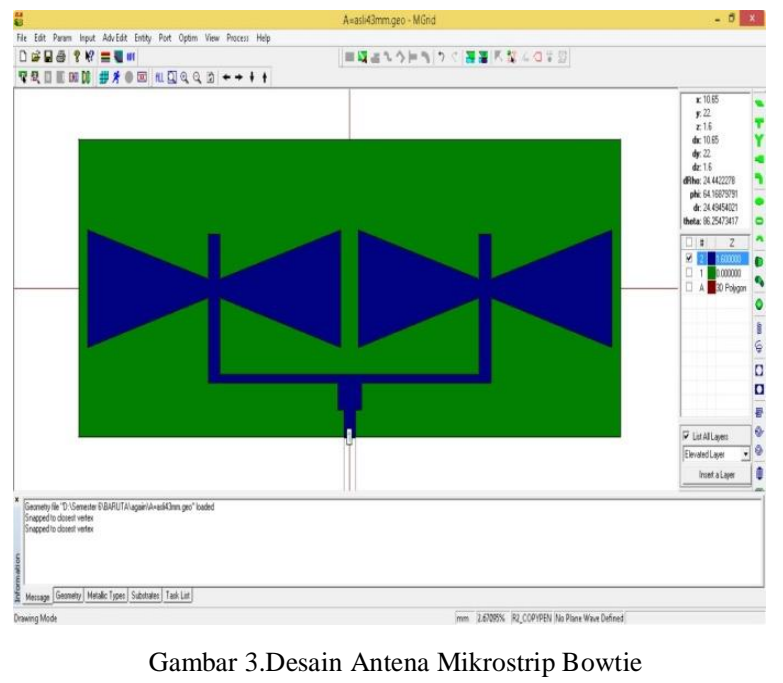

III. HASIL DAN PEMBAHASAN

\section{A. Hasil Pengukuran (Fabrikasi)}

Hasil pengukuran (fabrikasi) seperti yang tampak pada gambar 4 .

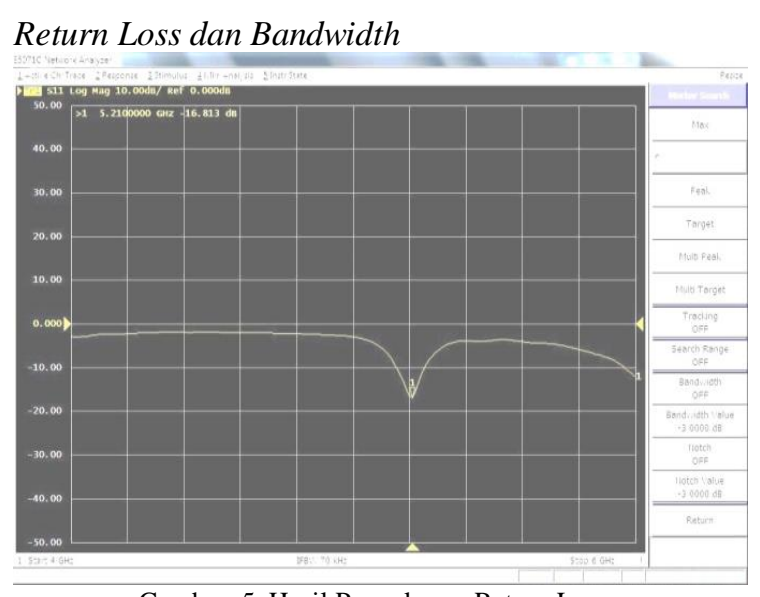

Gambar 5. Hasil Pengukuran Return Loss 


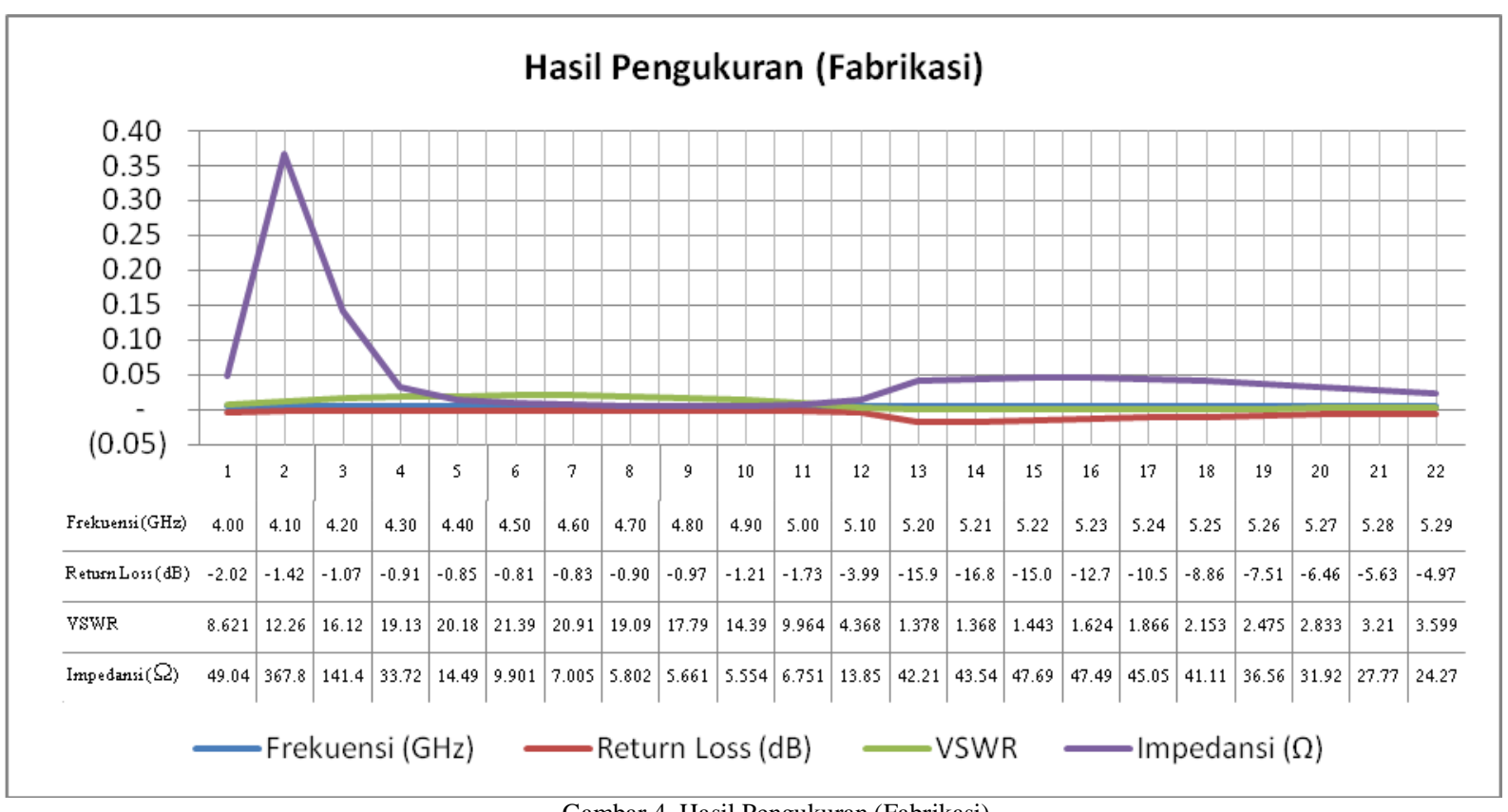

Berdasarkan pengukuran yang telah dilakukan terhadap antena mikrostrip bowtie maka didapatkan hasil return loss, bandwidth dan frekuensi resonansi. Berdasarkan gambar $5 \mathrm{di}$ atas, hasil pengukuran terhadap return loss pada frekuensi $5,21 \mathrm{GHz}$ adalah sebesar 16,813 dB. Grafik ini didapat dari hasil pengukuran Network Analyzer dari gambar 4

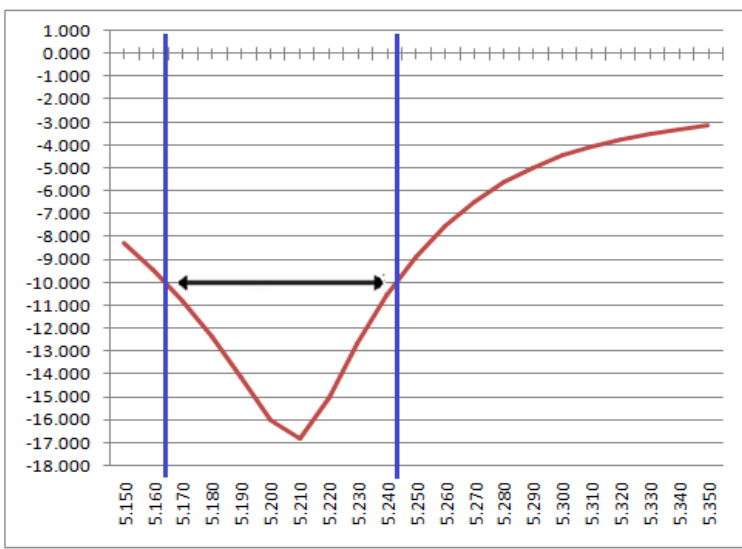

Gambar 6. Grafik Hasil Pengukuran Bandwidth

Untuk hasil range bandwidth dari gambar 5 diatas didapatkan hasil pengukuran yaitu $5,164 \mathrm{GHz}$ untuk frekuensi lower dan 5,243 GHz untuk frekuensi upper maka nilai bandwidth dapat dihutung dengan: $\mathrm{BW}($ pengukuran $)=\mathrm{f}($ upper $)-\mathrm{f}($ lower $)$

$$
\begin{aligned}
& =5,243 \mathrm{GHz}-5,164 \mathrm{GHz} \\
& =0,079 \mathrm{GHz} \\
& =79 \mathrm{MHz}
\end{aligned}
$$

VSWR

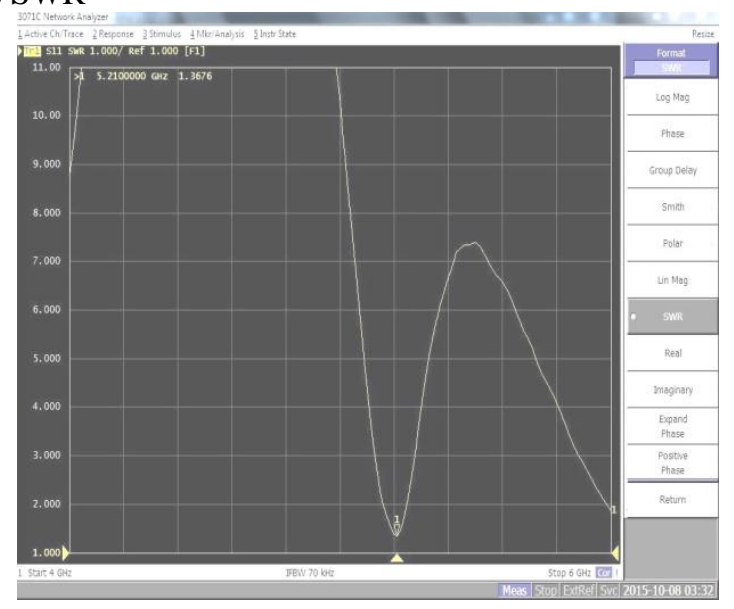

Gambar 7. Grafik Hasil Pengukuran VSWR

Berdasarkan percobaan yang telah dilakukan maka didapatkan hasil pengukuran VSWR menggunakan Network Analyzer. Pada gambar 7, nilai VSWR dari hasil pengukuran yaitu sebesar 1,3676. Grafik ini didapat dari hasil pengukuran Network Analyzer dari gambar 4.

\section{Pola Radiasi}

Untuk pola radiasi yang didapatkan pada pengukuran bentuk dari pola radiasinya adalah unidirectional. Karena antena hanya memancar satu arah, daerah daya pancarnya terdapat pada warna merah. Berikut merupakan hasil pengukuran berbentuk 3 dimensi. Untuk gambar 8 merupakan pola radiasi 3 dimensi, berikut bentuk pola radiasi untuk antenna mikrostrip bowtie. 


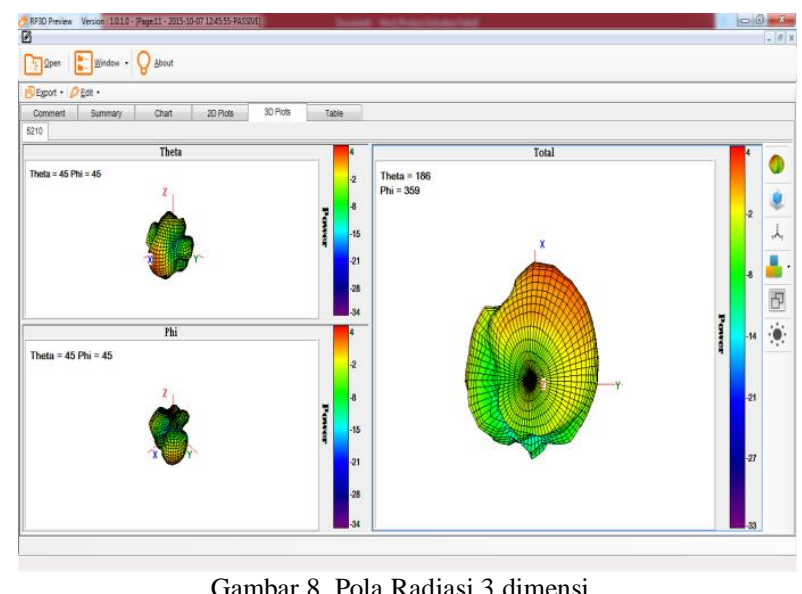

Gambar 8. Pola Radiasi 3 dimensi

\section{Pengukuran Impedansi}

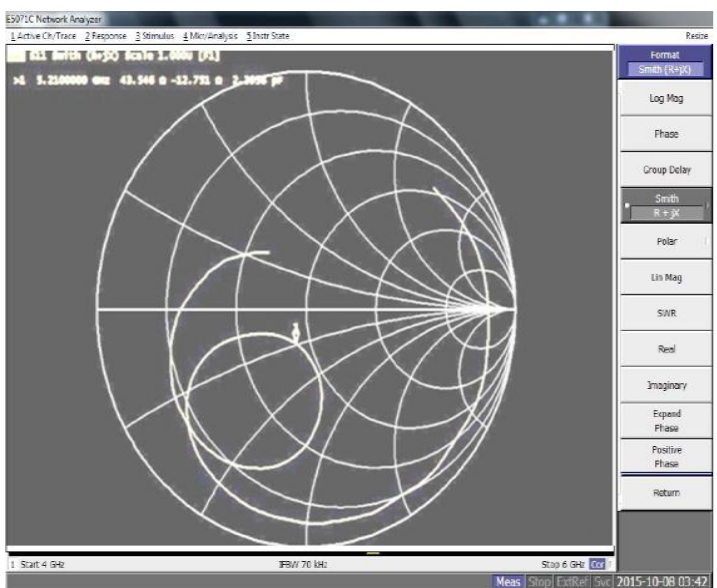

Gambar 9. Smithchart Pengukuran Impedansi

Berdasarkan pengukuran terhadap antena bowtie

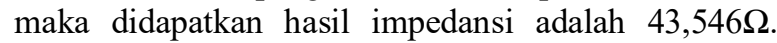
Nilai ini tidak sesuai dengan karakteristik antena

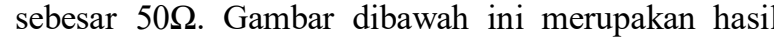
pengukuran impedansi pada Network Analyzer. Grafik ini didapat dari hasil pengukuran Network Analyzer dari gambar 4.

\section{B. Analisa dan Perbandingan Antena Hasil Simulasi dan Hasil Pengukuran}

Berdasarkan proses pengukuran yang telah dilakukan dengan desain antena yang didapatkan, antena menghasilkan nilai frekuensi yang jauh berbeda antara hasil simulasi dan pengukuran. Pada saat dilakukan pengukuran terhadap antena nilai frekuensi yang didapat adalah 4.7 GHz. Nilai tersebut jauh dari frekuensi antena yang diinginkan yaitu 5,2 $\mathrm{GHz}$ yang memiliki range 5,15-5,35 GHz. Antena yang telah dilakukan proses pengukuran terhadap desain awal harus memiliki hasil yang sama dengan apa yang disimulasikan. Untuk mendapatkan frekuensi yang sama, penulis melakukan perubahan ukuran terhadap antena. Penulis melakukan pengurangan panjang patch pada tiap sisi antena bowtie sebesar 3 mm sehingga didapatkan frekuensi yang sama dengan kriteria antena yang dibutuhkan. Setelah dilakukan pengurangan terhadap ukuran antena didapatkan frekuensi sebesar 5,21 GHz.

\section{Return Loss dan Frekuensi Resonansi}

Proses pengukuran terhadap parameter-parameter antena saat ini sudah dilakukan dengan alat yang modern dengan alat yang lebih bagus dan lebih baik. Hasil yang didapatkan lebih maksimal dibandingkan dengan pengukuran secara manual. Proses pengukuran antena ini dilakukan khusus yaitu ruangan Anechoic Chamber.

Berikut ini merupakan perbandingan nilai return loss dan frekuesi resonansi terhadap hasil pengukuran antena dan hasil simulasi yang digambarkan ke dalam bentuk grafik.

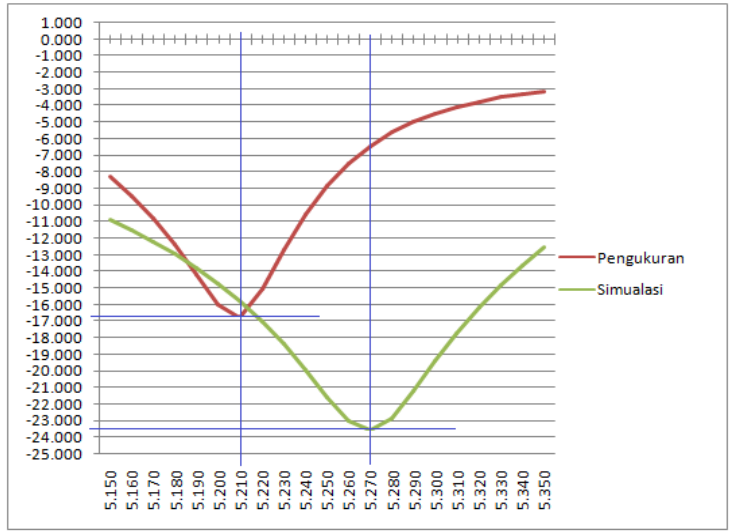

Gambar 10. Perbandingan Nilai Return Loss dan FrekuensiResonansi

Berdasarkan gambar 10 di atas dapat dianalisa bahwa resturn loss pada hasil simulasi lebih besar dibandingkan dengan antena hasil fabrikasi. Pada simulasi nilai return lossnya sebesar $-23,595 \mathrm{~dB}$ dan pada pengukuran sebesar $-16,513 \mathrm{~dB}$. Hal ini dapat terjadi pada saat proses pemindahan antena dari rancangan ke papan PCB dan nilai konstanta dielektrik yang tidak di ketahui. Hal ini berarti daya yang diserap kecil dan yang dipantulkan besar.

Untuk frekuensi resonansi dimana nilai minimum dari antena. Untuk hasil simulasi frekuensi resonansinya adalah $5,270 \mathrm{GHz}$ dan untuk hasil fabrikasi yaitu sebesar 5,21 GHz. Keduanya frekuensi ini masih berada pada range frekuensi 5,2 GHz.

\section{Bandwidth}

Bandwidth merupakan suatu range frekuensi dimana antena dapat beroperasi dengan kinerja yang baik. Berikut ini merupakan hasil perbandingan bandwidth antara simulasi dan pengukuran dengan menggunakan persamaan 2.4 dapat dihitung : 


$$
\text { BW }(\mathrm{MHz})=\mathrm{f}(\text { upper })-\mathrm{f}(\text { lower })
$$

$\mathrm{BW}($ simulasi $) \quad=\mathrm{f}($ upper $)-\mathrm{f}($ lower $)$

$$
=5,370 \mathrm{GHz}-5,140 \mathrm{GHz}
$$$$
=0,23 \mathrm{GHz}
$$

$$
=230 \mathrm{MHz}
$$

$\mathrm{BW}($ pengukuran $)=\mathrm{f}($ upper $)-\mathrm{f}($ lower $)$

$$
\begin{aligned}
& =5,243 \mathrm{GHz}-5,164 \mathrm{GHz} \\
& =0,079 \mathrm{GHz} \\
& =79 \mathrm{MHz}
\end{aligned}
$$

Dapat dilihat pada perhitungan diatas, bandwidth hasil simulasi lebih baik dari pada pengukuran sesuai dengan frekuensi antena. Hal ini dapat terjadi pada saat proses pemindahan desain ke papan PCB dan konstanta dielektrik yang tidak diketahui.

\section{Voltage Standing Wave Ratio (VSWR)}

Nilai VSWR yang baik untuk suatu antena adalah kecil dari 2 dan akan lebih baik jika VSWR kecil dari 1. Berikut merupakan perbandingan hasil simulasi dan pengukuran.Berdasarkan gambar 11 di bawah ini didapatkan nilai VSWR hasil simulasi sebesar 1,142 dan pada pengukuran 1,368. Hasil simulasi lebih bagus dari pada hasil pengukuran. Hal ini dapat terjadi karena ukuran saluran yang kurang tepat, konektor SMA yang impedansinya sudah turun atau pun ketidaktelitian dalam pembuatan antenna.

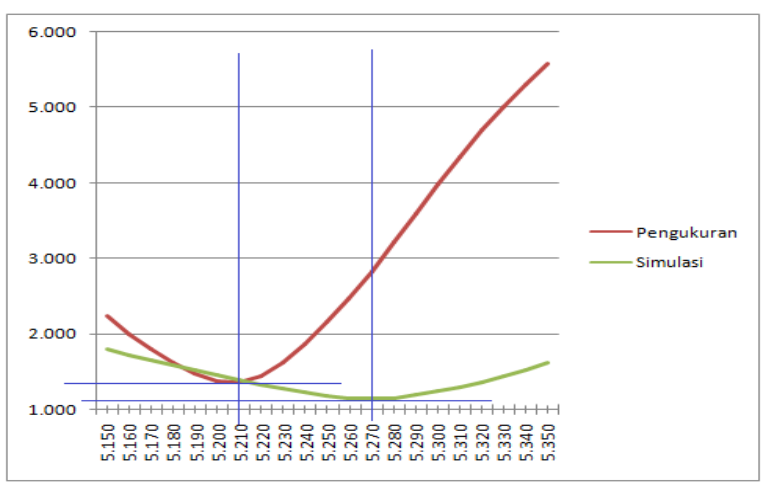

Gambar 11. Perbandingan Nilai VSWR Simulasi dan Pengukura

\section{Pola Radiasi}

Berdasarkan Gambar 12 di bawah ini merupakan hasil pengukuran dimana bentuk pola radiasi antena adalah unidirectional dimana intensitas pancaran dan penerimanya hanya satu tempat atau satu arah. Dengan bentuk pola radiasi unidirectional, pancaran antena mampu mempunyai jarak yang lebih jauh. Tetapi pola radiasi ini hanya bisa melingkupi suatu daerah pada arah tertentu. Hal ini menunjukkan hasil simulasi dan pengukuran sama. Gambar 11 didapat dari hasil pengukuran pada gambar 12 .
Impedansi merupakan perbandingan daya yang ada pada bagian terminal antena. Berikut merupakan perbandingan hasil simulasi dan hasil pengukuran. Berdasarkan gambar 13 impedansi hasil simulasi yang didapatkan sebesar 43,919 $\Omega$ dan hasil pengukuran didapatkan sebesar 43,546 $\Omega$. Impedansi yang didapatkan sama dengan yang disimulasikan. Nilai tersebut tidak sesuai dengan karakteristik antena yaitu sebesar $50 \Omega$. Hal ini terjadi karena penulis kurang memaksimalkan nilai impedansi yang dilakukan pada simulasi. Grafik didapatkan dari hasil simulasi dan pengukuran dari gambar 12 .

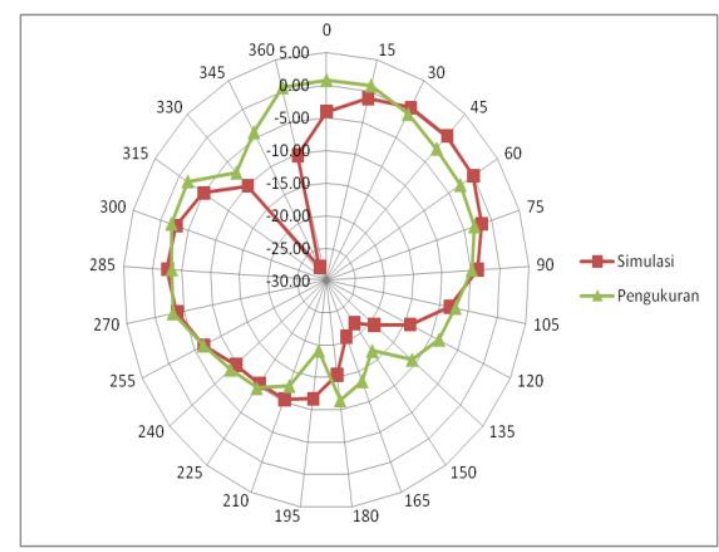

Gambar 13. Perbandingan Pola Radiasi Hasil Simulasi dan Pengukuran

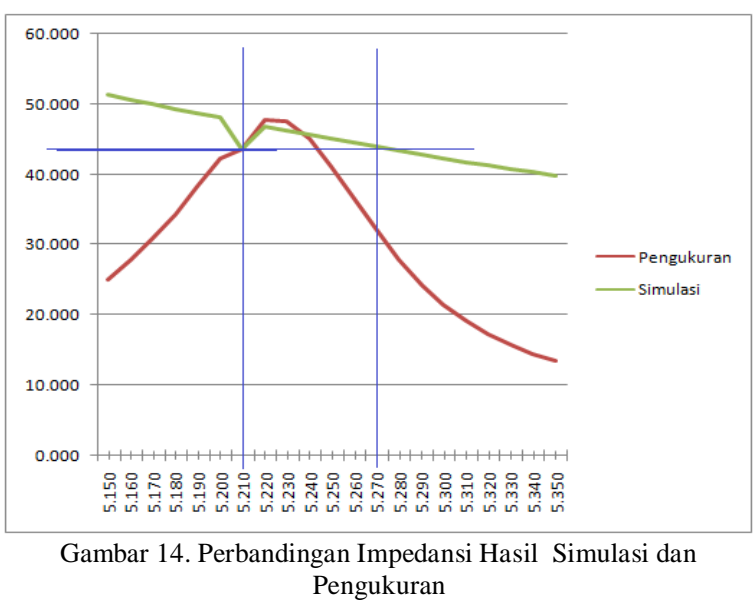

\section{Perbandingan Parameter Antena}

Pada tabel 1 dibawah ini dapat dilihat perbandingan nilai parameter-parameter antena dari hasil simulasi dan hasil pengukuran.

\section{Impedansi}




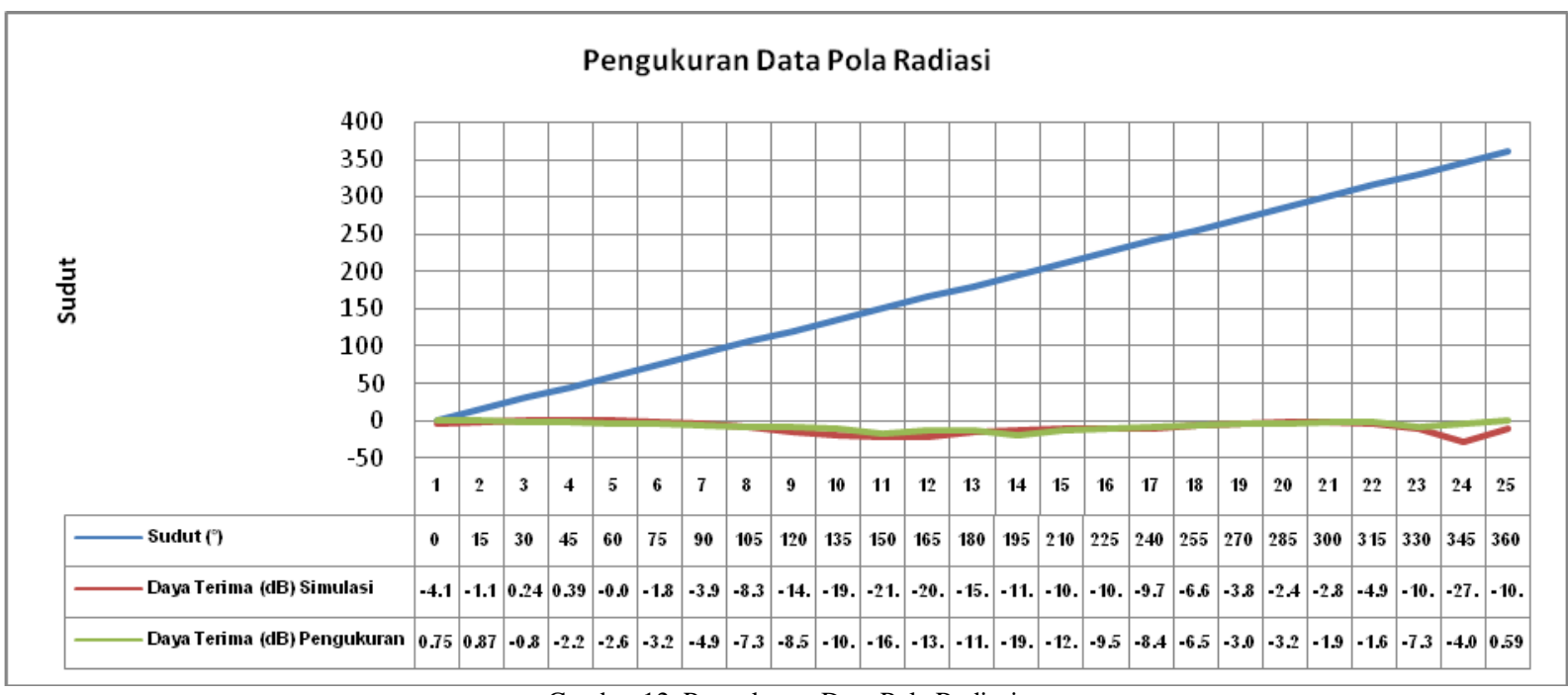

Gambar 12. Pengukuran Data Pola Radiasi

Tabel 1. Perbandingan Parameter Antena Bowtie Simulasi dan Pengukuran

\begin{tabular}{ccc} 
& dan Pengukuran & \\
\hline Parameter Antena & Simulasi & Pengukuran \\
\hline Frekuensi Resonansi & $5,270 \mathrm{GHz}$ & $5,21 \mathrm{GHz}$ \\
\hline Return Loss & $-23,595 \mathrm{~dB}$ & $-16,813 \mathrm{~dB}$ \\
\hline VSWR & 1,142 & 1,368 \\
\hline Bandwidth & $230 \mathrm{MHz}$ & $79 \mathrm{MHz}$ \\
\hline Pola radiasi & Unidirectional & Unidirectioanal \\
\hline Impedansi & $43,919 \Omega$ & $43,546 \Omega$ \\
\hline
\end{tabular}

Dari tabel 1 di atas dapat dilihat perbandingan parameter antena yang telah difabrikasi dan simulasi yang telah dilakukan secara keseluruhan. Perbandingan di atas menunjukan bahwa hasil simulasi lebih bagus dari pada antena yang telah difabrikasi. Hal ini terjadi karena pada saat proses pemindahan desain antena ke papan PCB kurang tepat dan bisa juga terjadi karena proses pelarutannya. Ketidakpastian nilai konstanta dielektrik terhadap papan PCB juga memicu factor ketidaksesuaian hasil pengukuran dengan hasil simulasi. Dan karena ukuran saluran yang kurang tepat, konektor SMA yang impedansinya sudah turun.

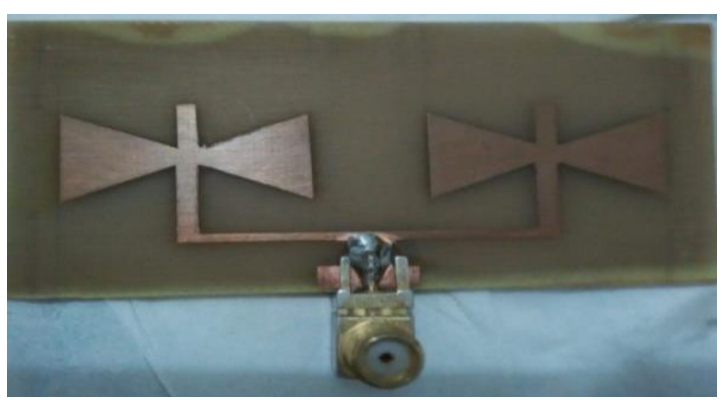

Gambar 15. Antena Hasil Perancangan

\section{KESIMPULAN}

Berdasarkan hasil simulasi, pengukuran antena, data hasil pengukuran serta analisa yang telah penulis lakukan maka dapat diambil kesimpulan,

1. Frekuensi resonansi antena mikrostrip bowtie yaitu $5,21 \mathrm{GHz}$ pada pengukuran dan $5,269 \mathrm{GHz}$ pada simulasi.

2. Return Loss antena mikrostrip bowtie yaitu $16,813 \mathrm{~dB}$ pada pengukuran dan $-23,595 \mathrm{~dB}$ pada simulasi.

3. Antena mikrosrtip bowtie memiliki bandwidth 79 $\mathrm{MHz}$ pada pengukran dan $230 \mathrm{MHz}$ untuk simulasi.

4. Untuk return loss dan bandwidth hasil antara simulasi dan pengukuran terlalu jauh bedanya dikarenakan nilai konstanta dielektrik pada papan PCB tidak diketahui dan juga biasa terjadi pada saat pemindahan antena dari rancangan ke papan PCB kurang tepat.

5. Polaradiasi antena mikrostrip bowtie memiliki pola radiasi unidirectional pada simulasi dan pengukuran.

6. VSWR antena mikrostrip bowtie memiliki 1,142 untuk simulasi dan 1,368 untuk pengukuran.

7. Antena mikrostrip bowtie memiliki impedansi $43,919 \Omega$ untuk simulasi dan 43,546 $\Omega$ untuk pengukuran dan HPBW sebasar $105^{\circ}$.

8. Antena mikrostrip bowtie $5,2 \mathrm{GHz}$ dapat diaplikasi WLAN (Wireless Local Area Network) dan layanan pita lebar Nirkabel (Wireless Broadband) 


\section{REFERENSI}

[1] A. Wahyu , A. E.Jayati, S. Heranurweni.2014" Rancang Bangun Antena Microstrip $900 \mathrm{MHz}$ Untuk Sistem GSM". Jurnal Sains, Teknologi dan Industri, Vol. 12, No. 1,67 - 72

[2] Kurniati, E, 2009. "Perancangan dan Pembuatan Antena Mikrostrip Bowtie 2,4 GHz Untuk Penerimaan Sinyal WIRELESS-LAN". Program Diploma. Padang: Teknik Elektro PNP

[3] Denny, T, 2010. Antena Micky. Universitas Brawijaya

4] Mahendra, A, 2012. Perancangan Antena Mikrostrip Bowtie pada Aplikasi Ultra Wideband. Jakarta: Teknik Elektro Universitas Pancasila

[5] MN. Silalahi. 2013. Antena Mikrostrip. Medan: Universitas Sumatera Utara.

[6] Muhtadi, D, 2010. "Antena Mikrostrip Slot Berstruktur Kupukupu Dengan Feeding Co-Planer Waveguide”. Program Studi Pascasarjana. Surabaya: Fisika FMIPA ITS
[7] Saidin Tutang, A, dkk. Antena Mikrostrip Slot Bowtie Single Array dengan Pandu Gelombang CoPlanar Untuk KomunikasinWireless pada Frekuensi 2,4 GHz. Universitas Hasanuddin.

[8] Hidayat, T, 2012. "Rancang Bangun Antena Mikrostrip Susun Menggunakan Jenis Pencatuan Aperture Coupled Dengan Slot Berbentuk Jam Pasir". Sarjana Teknik Depok: Teknik Elektro Universitas Indonesia

[9] I.Ichwani, H. Wijanto, Y. Wahyu. 2017." Antena microstrip fractal - bowtie 2-18 GHz Untuk electronic support measure". e- Proceeding of Engineering : Vol.4, No.2 